\title{
PENDAMPINGAN METODE MENGGAMBAR, MEWARNAI, DAN MENGECAT PADA GURU DALAM MENINGKATKAN MOTORIK ANAK DI PAUD KEMAH KASIH PADEMANGAN BARAT, JAKARTA UTARA
}

\author{
Oleh: \\ Pieter Anggiat Napitupulu ${ }^{1}$ Bobby Kurnia Putrawan ${ }^{2}$, Sutrisno ${ }^{3}$ \\ Sekolah Tinggi Teologi STAPIN, Majalengka \\ pieternapitupulu@yahoo.co.id
}

\begin{abstract}
Abstrak
Profesional dan kualitas guru PAUD berpengaruh pada kualitas siswa, termasuk didalamnya adalah motorik siswa. Dengan demikian, diperlukan peningkatan profesionalisme dan kualitas guru PAUD dalam mengajar dan dalam hal ini adalah metode pembelajaran. Berkenaan dengan peningkatan motorik siswa, maka guru PAUD perlu dibekali dan ditingkatkan metode pembelajaran yang tepat dan kreatif. Beberapa metode pembelajaran yang berkaitan dalam peningkatan motorik siswa adalah menggambar, mewarnai, dan mengecat. Metode yang dilakukan dalam kegiatan pengabdian kepada masyarakat ini adalah dengan pendampingan. Hasil dari kegiatan ini adalah meningkatnya motorik siswa di PAUD Kemah Kasih. Peningkatan motorik siswa berdampak pada meningkatknya fokus atau konsentrasi, kesabaran, keterampilan, emosi, ketaatan, ketepatan dalam mengisi obyek, disiplin, kreatifitas, pantang menyerah (menyelesaikan tugas sampai selesai) pada siswa PAUD Kemah Kasih.
\end{abstract}

Kata kunci: metode pembelajaran, menggambar, mewarnai, mengecat, guru PAUD.

\begin{abstract}
Professional and quality of early childhood teachers have an effect on the quality of students, including students' motor skills. Thus, it is necessary to increase the professionalism and quality of PAUD teachers in teaching and in this case is the learning method. With regard to improving student motor skills, PAUD teachers need to be equipped and enhanced with appropriate and creative learning methods. Several learning methods related to improving students' motor skills are drawing, coloring, and painting. The method used in this community service activity is assistance. The result of this activity was the improvement of the students' motor skills at the Kemah Kasih PAUD. The increase in student motoric has an impact on increasing focus or concentration, patience, skill, emotion, obedience, accuracy in filling objects, discipline, creativity, never giving up (completing assignments to completion) in Kemah Kasih PAUD students.
\end{abstract}

Keywords: learning methods, drawing, coloring, painting, PAUD teachers.

\section{PENDAHULUAN}

Guru Pendidikan Anak Usia Dini (PAUD) merupakan unsur penting dalam meningkatkan kualitas sumber daya manusia yang dalam konteks ini anak-anak usia dini. Beranjak dari Undang-Undang Republik Indonesia Nomor 14 Tahun 2005 Tentang Guru dan Dosen pada Bab I Pasal 1 ayat 2 mengatakan bahwa seorang guru merupakan seorang pendidik yang ilmuwan dan profesional dimana memiliki tugas utama melakukan perubahan, pengembangan, dan penyebarluasan ilmu pengetahuan, teknologi, dan seni melalui pendidikan, penelitian, dan pengabdian kepada masyarakat (UndangUndang Nomor 14 Tahun 2005, 2005). Penelitian dan Pengabdian kepada Masyarakat merupakan satu faktor ukuran penting untuk guru/tenaga pendidik. Kegiatan Penelitian dan Pengabdian kepada 
Masyarakat (P2M) di Sekolah Tinggi Teologi STAPIN Majalengka dan Sekolah Tinggi Teologi Moriah Tangerang memiliki tugas untuk mengembangkan pelbagai macam pemberdayaan, bagaimana menerapkannya, dan melakukan pendampingan pada kehidupan masyarakat dalam mencapai tujuan pendidikan nasional dan pembangunan Negara di segala bidang, serta meningkatkan kerja sama pelbagai lembaga baik lembaga swasta dan lembaga pemerintah.

Permasalahan yang muncul dalam pembelajaran adalah sebagian guru belum memiliki profesionalisme dan kualitas yang memadai. Guru PAUD mengajar hanya sebatas formalitas tugas dan tuntutan pekerjaan. Guru PAUD kurang memiliki kualitas metode pembelajaran dan keterampilan yang memadai. Hal ini berdampak pada pertumbuhan dan perkembangan siswa untuk mencapai tujuan pendidikan, yaitu menjadi manusia yang utuh.

Guru PAUD merupakan satu faktor keberhasilan dalam mencapai tujuan pendidikan, karena tugas utama guru adalah mengatur kelas, mengajar, dan mefasilitasi perkembangan belajar anak. Dengan demikian, seorang guru PAUD diharapkan mampu memiliki hubungan yang baik dengan siswanya. Selain memiliki hubungan baik, maka seorang guru PAUD dituntut memiliki profesionalisme dan kualitas. Dalam hal ini, maka seorang guru PAUD harus memiliki metode pembelajaran yang tepat, kreatif, efektif, dan adaptif dengan keberadaan siswa di segala keadaan seperti yang tercantum dalam Peraturan Menteri Pendidikan Nasional Nomor 16 Tahun 2007 tentang Standar Kualifikasi Akademik dan Kompetensi Guru yang meliputi kompetensi kepribadian, kompetensi pedagogik, kompetensi sosial dan kompetensi profesional yang diperoleh melalui pendidikan profesi (Peraturan Menteri Pendidikan Nasional Nomor 16 Tahun 2007).

Satu aspek pendidikan yang pentingnya adalah pembentukan motorik dari siswa. Aspek motorik dari siswa bepengaruh penting dalam pembentukan manusia yang utuh.
Aspek motorik ini membentuk fokus atau konsentrasi, kesabaran, keterampilan, emosi, ketaatan, ketepatan dalam mengisi obyek, disiplin, kreatifitas, pantang menyerah (menyelesaikan tugas sampai selesai) pada siswa. Maka peneliti hanya memberikan pendampingan tiga (3) metode pembelajaran, sebagai berikut:

\section{Metode Menggambar}

Saat menggambar, seorang anak dihadapkan pada berbagai keputusan apakah itu 'warna apa yang harus saya gunakan di sini?' Atau 'Bagaimana cara menggambar binatang dan menghubungkan satu bagian tubuhnya dengan yang lain?' Semua pertanyaan ini mengharuskan mereka untuk memecahkan masalah. Menggambar memungkinkan imajinasi anak Anda menjadi lebih aktif. Setiap kali menggambar, mereka mengakses imajinasinya dan membuat representasi fisik dari apa yang ada dalam pikiran mereka. Imajinasi orang telah memungkinkan mereka untuk menciptakan semua hal yang kita gunakan dan dikelilingi oleh kehidupan sehari-hari (Baroutsis, Kervin, Woods, \& Comber, 2017; Tay-Lim \& Lim, 2013).

Menggambar adalah salah satu fondasi awal pemikiran logis atau pemikiran abstrak. Baik anak Anda masih di rumah bersama Anda atau di sekolah, menggambar membantu mereka mempersiapkan diri untuk memahami konsep yang lebih sulit. Mempelajari cara berpikir kreatif ini sejak usia dini mempersiapkan anak untuk pendidikan di masa depan. Sehingga dapat disimpulkan bahwa menggambar menanamkan karakter yang baik seperti bertanggung jawab, disiplin, menghargai suatu karya, dan kreatif (Hope, 2012; Putri \& Trisakti, 2019).

\section{Metode Mewarnai}

Penggunaan warna dalam bahan ajar telah terbukti memainkan peran penting dalam menciptakan reaksi emosional yang berbeda dan menarik perhatian anak. Mewarnai dapat memengaruhi pembelajaran dengan memanipulasi kognisi dan emosi mereka. Mewarnai mempengaruhi kinerja memori anak dan beban kognitif mereka, dan bagaimana warna merangsang emosi anak dan selanjutnya memotivasi anak untuk belajar. Praktek pemilihan warna yang dapat digunakan untuk membantu anak meningkatkan perhatian mereka pada materi 
dan membantu guru melihat hubungan antara warna, emosi, dan pembelajaran kognitif. Emosi positif dapat meningkatkan hasil kognitif dan afektif. Mengetahui bagaimana warna mempengaruhi perilaku adalah informatif dalam hal bagaimana menggunakan warna yang membangkitkan semangat (warna hangat seperti merah, oranye, dan kuning) untuk mencegah peserta didik bosan, dan rona pasif (warna dingin seperti hijau dan biru) untuk menjaga agar peserta didik tetap tenang (Chang et al., 2018).

\section{Metode Mengecat}

Proses pembelajaran di PAUD ditekankan pada pengembangan proses berpikir dan proses kreatif yang sesuai dengan tingkat kecerdasan yang dimiliki anak. Kualitas tumbuh kembang anak ditentukan sejak mereka menginjak usia lima tahun. Proses peningkatan keterampilan motorik anak dapat dilakukan dengan kegiatan mengecat. mengecat yang dimaksud dengan kegiatan menyusun campuran warna. Kegiatan ini juga dapat meningkatkan perkembangan motorik halus dan aspek sosial emosional anak serta pengenalan konsep warna pada anak.

Kegiatan mengecat dirancang untuk mengukur kemampuan motorik kasar dan motorik halus anak usia 5-6 tahun. Hasil penelitian diperoleh mengenai perkembangan motorik kasar dan halus anak usia 5-6 tahun pada kegiatan mengecat. Data yang disajikan dalam penelitian ini adalah capaian perkembangan motorik kasar dan motorik halus pada anak usia 5-6 tahun dalam kegiatan mengecat. mengecat memberikan pengalaman belajar dan eksplorasi bagi anak-anak. Mengecat dapat membantu anakanak dalam proses belajar pengenalan warna (Lali, F, Sutarto, \& Setiawan, 2020). Seperti juga yang dihasilkan oleh penelitian Zuliatin bahwa pengetahuan warna yang menunjukkan bahwa terdapat perbedaan antara anak yang diberikan pelatihan mengecat dengan anak yang tidak diberikan pelatihan dalam memperoleh pengetahuan tentang warna. warna. Pelatihan mengecat lebih baik atau lebih tinggi daripada anak yang tidak diberi pelatihan mengenal warna (Hope, 2012; Zuliatin, Farid, \& Denog, 2013).

Tujuan dari kegiatan ini adalah pertama, meningkatkan profesionalitas dan kualitas guru-guru PAUD tentang metode menggambar, mewarnai, dan melukis. Kedua, meningkatkan kemampuan guru dalam kreatifitas dalam pembelajaran PAUD.

\section{METODE}

Kegiatan ini merupakan penelitian dan pengabdian kepada masyarakat (P2M) dilaksanakan pada tanggal 8 sampai 29 April 2020 bertempat di PAUD Kemah Kasih, Kecamatan Pademangan Barat, Jakarta Utara. Kegiatan yang dilaksanakan meliputi pendampingan metode pembelajaran menggambar, mewarnai, dan melukis bagi guru-guru PAUD yang berumlah 5 orang dan jumlah siswa 32 anak.

Metode dari kegiatan pengabdian kepada masyarakat dilaksanakan, sebagai berikut:

1. Menganalisa keadaan sekolah di PAUD Kemah Kasih, Pademangan Barat, Jakarta Utara.

2. Menentukan dan membatasi permasalahan berdasarkan hasil analisa keadaan sekolah.

3. Membangun studi literatur yang berbasiskan dari latar belakang masalah setelah menganalisa keadaan sekolah.

4. Membangun, merancang, dan menguji sistem pembelajaran dan pendampingan kegiatan.

5. Melakukan pendampingan dan sosialisasi dari kegiatan pengabdian kepada masyarakat ke segenap pemangku kepentingan di PAUD Kemah Kasih.

6. Melakukan evaluasi kegiatan. Evaluasi ini bertujuan untuk menganalisa dan mengetahui hasil kegiatan, serta sebagai bentuk pelaporan ke Sekolah Tinggi Teologi STAPIN dan Sekolah Tinggi Teologi Moriah. pada:

Kegiatan pendampingan ini ditujukan

Pertama, guru-guru yang mengajar di PAUD Kemah Kasih Kecamatan Pademangan Barat Jakarta Utara berjumlah 5 orang yang mengikuti pendampingan pada tanggal 8 sampai 29 April 2020. Kedua, siswa-siswi PAUD Kemah Kasih di Pademangan Barat sejumlah 32 anak.

\section{HASIL DAN PEMBAHASAN}

Hasil kegiatan pendampingan metode pembelajaran dilakukan sebagai berikut:

Kegiatan Pendampingan pada Tanggal 8 April 2020 
Pada pertemuan pertama, peneliti tiba di PAUD Kemah Kasih di Kecamatan Pademangan Barat dan bertemu dengan pimpinan PAUD. Kegiatan ini dilaksanakan Pukul 10.00 WIB dengan dibuka oleh ketua yayasan kemah kasih. Adapun kegiatan yang dilakukan antara lain:

1. Doa pembukaan oleh guru PAUD.

2. Pembukaan dan kata sambutan dari ketua yayasan kemah kasih, Drs. Doni Hermawan.

3. Kata sambutan kepala sekolah PAUD Kemah Kasih.

4. Perkenalan peneliti kepada Guru-guru PAUD Kemah Kasih.

5. Pendampingan mengenai pengetahuan metode pembelajaran menggambar, mewarnai, dan melukis.

6. Memberikan beberapa contoh metode pembelajaran menggambar, mewarnai, dan melukis sesuai dengan Rencana Pembelajaran Semester (RPS) pada pimpinan dan guru-guru PAUD.

7. Sesi seminar yang disertai dengan Tanya jawab dengan guru-guru PAUD mengenai metode pembelajaran yang sesuai dengan pokok bahasan yang akan diajarkan.

8. Warna sari.

9. Rencana melanjutkan kegiatan praktek metode pembelajaran yaitu setiap hari Rabu tanggal 15, 22, 29 April 2020.

Kegiatan Praktek Metode Pembelajaran Menggambar pada Tanggal 15 April 2020

Pada kegiatan praktek pendampingan metode pembelajaran menggambar pada tanggal 15 April 2020, penulis mendampingi guru-guru PAUD melalukan metode pembelajaran menggambar sesuai arahan kepala sekolah PAUD. Adapun kegiatan menggambar disini adalah penguatan motorik untuk membuat garis lurus, lengkung, bentuk bulat, kotak, segitiga.

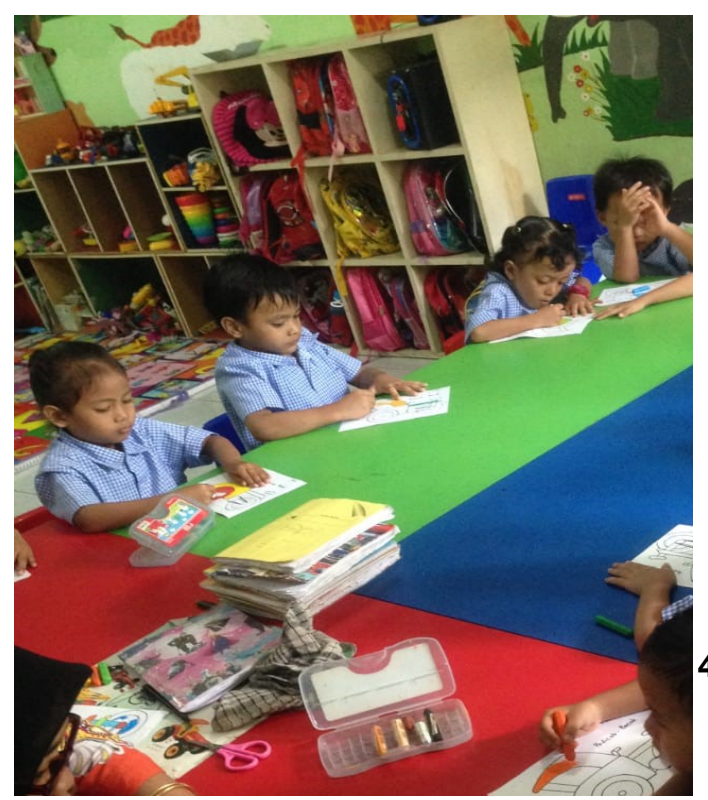

Gambar 1. Kegiatan Menggambar

Kegiatan Praktek Metode Pembelajaran Menggambar pada Tanggal 22 April 2020

Pada kegiatan praktek pendampingan metode pembelajaran mewarnai dilakukan pada tanggal 22 April 2020, peneliti mendampingi guru-guru PAUD melalukan metode pembelajaran mewarnai. Adapun kegiatan mewarnai disini adalah mengenal warna jenis padat, cara memegang alat tulis dengan benar, menjelaskan fungsi-fungsi alat tulis, mewarnai tidak keluar garis, dan mewarnai sampai penuh.

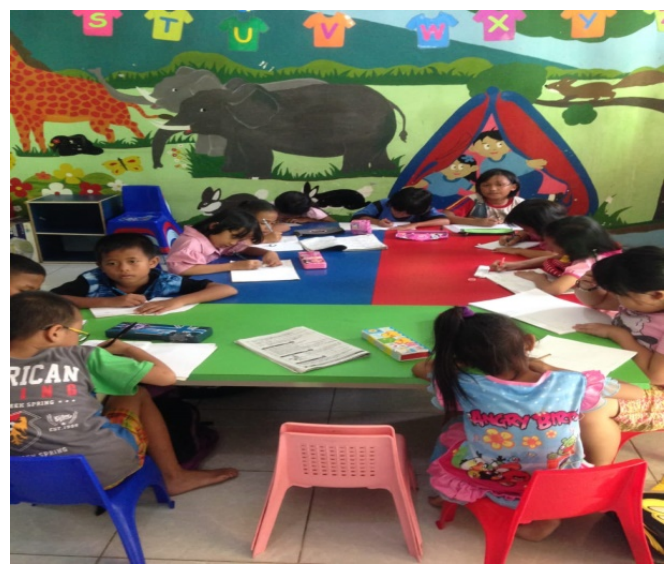

Gambar 2. Kegiatan Mewarnai

Kegiatan Praktek Metode Pembelajaran Melukis pada Tanggal 29 April 2020

Pada kegiatan praktek pendampingan metode pembelajaran mengecat dilakukan pada tanggal 29 April 2020, peneliti mendampingi guru-guru PAUD melalukan metode pembelajaran mewarnai. Adapun kegiatan mengecat disini adalah mengenal warna jenis cair, tidak takut kotor, keberanian, harmonisasi warna.

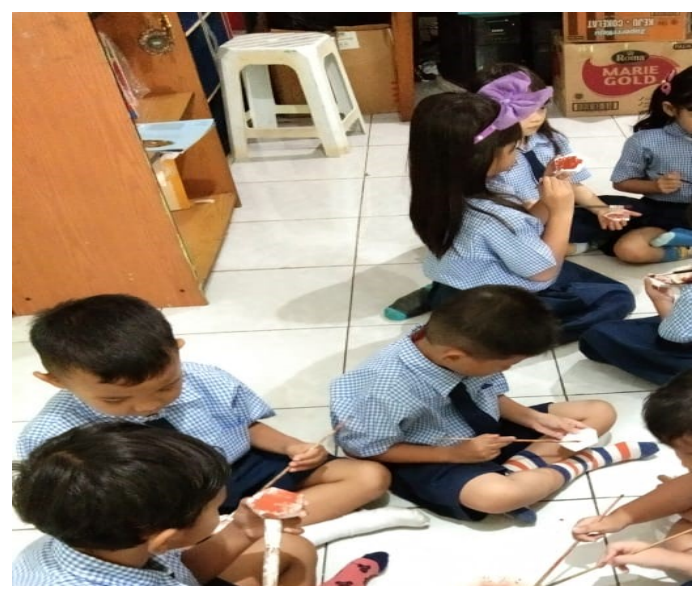




\section{Gambar 3. Kegiatan Melukis}

\section{Kegiatan Penutupan}

Kegiatan penutupan dilakukan dengan ucapan terima kasih, doa bersama, door prize, disertai foto bersama pada tanggal 29 April 2020.

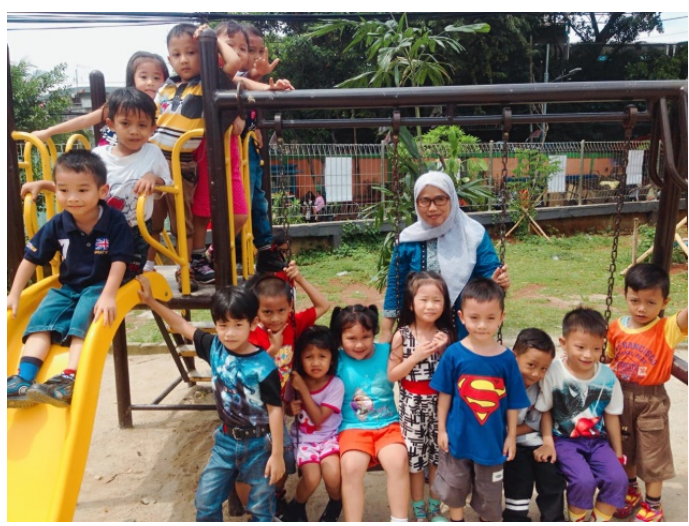

Gambar 4. Penutupan

\section{Pembahasan}

Dalam menggali suara anak kecil atau siswa, kita memposisikan siswa sebagai informan yang kompeten dan ahli tentang pembelajarannya sendiri. Dalam banyak konteks pendidikan, pemahaman tentang menulis tanpa henti cenderung ke arah literasi versi sekolah yang digerakkan oleh kebijakan, tanpa pandangan siswa-siswi yang dianggap serius. Oleh karena itu, menghargai perspektif siswa tentang pembelajaran mendorong penghormatan terhadap identitas dan minat anak, memposisikan mereka sebagai ahli atas pengalaman mereka sendiri. Mengedepankan suara siswa-siswi dengan mendengarkan mereka juga berfungsi untuk memastikan bahwa, sebagai pendidik dan peneliti, kita bertanggung jawab kepada siswa-siswi (Baroutsis et al., 2017; Keiler, 2018).

Narasi siswa-siswi biasanya menggambarkan pemahaman 'tradisional' tentang pengalaman menggambar mereka, yaitu, bahwa menggambar, mewarnai, dan mengecat adalah aktivitas individu, dilakukan di ruang kelas sambil duduk di depan meja dan seterusnya. Namun, ketika siswa-siswi ditanyai tentang menggambar, mewarnai, dan mengecat mereka, mereka mengungkapkan banyak pengalaman dan preferensi untuk elemen relasional, material dan spasial dari gambar, warna, dan cat tersebut. Sebagai penutup, kami fokus pada beberapa preferensi anak-anak dalam narasi sebagai cara untuk mengedepankan kemungkinan dan, terkadang, celah dalam praktik menulis (Hope, 2012).

Menarik preferensi relasional siswa-siswi dengan menggambar, mewarnai, dan mengecat, maka dapat dipahami sebagai peserta aktif dalam proses membawa ide, motorik, dan emosi mereka ke dalam menggambar, mewarnai, dan mengecat. Gambar, warnai, dan cat mereka kebanyakan merepresentasikan apa yang ada pada pikiran dan emosinya sebagai kegiatan yang menyenangkan. Selain itu, meskipun identitas menggambar, mewarnai, dan mengecat siswa-siswi dipengaruhi oleh hubungan mereka dengan orang lain, sebagian besar siswa atau siswi tidak menyertakan representasi dari praktik menulis kolaboratif; Mereka yang menggambar, mewarnai, dan mengecat sebagai praktik kolaboratif memberi penekanan pada kolaborasi mereka dengan kelompok, seperti teman, guru, dan keluarga. Kedua, pengalaman menggambar, mewarnai, dan mengecat materi dan spasial siswa-siswi sebagian besar diwakili melalui meja dan kursi di lokasi dalam ruangan, seperti ruang kelas mereka. Kadang-kadang, komposisi mereka mengekspresikan materi menggambar, mewarnai, dan mengecat dalam skala yang membuat penulis memunculkan kemungkinan bahwa beberapa anak menganggap menggambar, mewarnai, dan mengecat adalah tugas yang sangat berat. Selain itu, melalui kegiatan ini, penulis memperoleh wawasan tentang beragam preferensi untuk menggambar, mewarnai, dan mengecat, seperti berdiri daripada duduk, dan menggunakan teknologi daripada pensil dan kertas (Baroutsis et al., 2017; Keiler, 2018; Tay-Lim \& Lim, 2013).

Dalam menganalisis gambar anak-anak, kami mengidentifikasi pengalaman anak-anak dengan menggambar, mewarnai, dan mengecat serta konteks relasional, material yang mereka sukai untuk menulis. Nilai di sini bagi pembuat kebijakan dan pendidik terletak pada mengatasi kesenjangan antara pengalaman dan preferensi siswa-siswi ini serta realitas waktu menggambar, mewarnai, dan mengecat di sekolah. Temuan paling mencolok adalah perbedaan antara representasi anak-anak dalam belajar menggambar, mewarnai, dan mengecat serta gagasan bahwa menggambar, mewarnai, dan mengecat di zaman kontemporer melibatkan orang-orang yang menggunakan berbagai alat, media, dan teknologi untuk menghasilkan teks multimodal bersama- 
sama. Di luar lingkup kami di sini untuk membahas mengapa hal ini mungkin terjadi. Kami dapat melaporkan bahwa para guru sangat tertarik dengan metode pembelajaran menggambar, mewarnai, dan mengecat untuk siswa-siswi tentang pengalaman mereka belajar menggambar, mewarnai, dan mengecat, serta sejumlah guru telah mulai bereksperimen dengan berbagai cara mengatur ruang kelas dan waktu untuk menggambar, mewarnai, dan mengecat langkah pertama yang diperlukan dalam mengeksplorasi kemampuan siswa-siswi. Dengan demikian, metode pembelajaran menggambar, mewarnai, dan mengecat berdampak pada meningkatnya fokus atau konsentrasi, kesabaran, keterampilan, emosi, ketaatan, ketepatan dalam mengisi obyek, disiplin, kreatifitas, pantang menyerah (menyelesaikan tugas sampai selesai) pada siswa-siswi PAUD Kemah Kasih.

\section{SIMPULAN DAN SARAN}

\section{Simpulan}

Beberapa poin yang dapat diberikan simpulan dari hasil kegiatan penelitian dan pengabdian kepada masyarakat ini, sebagai berikut:

1. meningkatnya pemahaman guru-guru PAUD tentang metode pembelajaran menggambar, mewarnai, dan mengecat bagi siswa-siswi PAUD dengan dilakukan pendampingan.

2. meningkatnya pemahaman guru-guru PAUD tentang pentingnya metode pembelajaran menggambar, mewarnai, dan mengecat bagi siswa-siswi PAUD dalam mempelajari materi-materi bahasan.

3. meningkatnya motorik siswa-siswa PAUD dengan terlihat pada focus atau konsentrasi, kesabaran, keterampilan, emosi, ketaatan, ketepatan dalam mengisi obyek, disiplin, kreatifitas, pantang menyerah (menyelesaikan tugas sampai selesai) dari siswa-siswi PAUD Kemah Kasih.

Saran

Berdasarkan evaluasi kegiatan pengabdian kepada masyarakat yang telah dilakukan, maka dapat diajukan beberapa saran sebagai berikut:

1. dibutuhkannya penambahan waktu pelaksanaan kegiatan penelitian dan pengabdian kepada masyarakat supaya mencapai tujuan kegiatan seperti yang diinginkan.

2. perlunya kegiatan lanjutan dalam bentuk pelatihan atau pendampingan metode pembelajaran secara berkala sehingga mampu meningkatkan profesionalitas dna kualitas guru dalam melakukan proses pembelajaran.

3. kegiatan ini tidak hanya terkonsentrasi pada para guru PAUD saja tetapi juga dilakukan pada tingkat pendidikan di atasnya yang berada di Kecamatan Pademangan Barat Kota Jakarta Utara.

\section{DAFTAR PUSTAKA}

Baroutsis, Aspa, Kervin L, Woods A, Comber B. 2019. Understanding Children's Perspectives of Classroom Writing Practices Through Drawings. Contemporary Issues in Early Childhood, 20(2), p.177-193.

Chang, Bo, Watt, Tiffany, Nourdad, Nava, Masoudi, Sanam, Rahimali, Parisa, Crump, W. Donald, Schlichter, Carol L., \& Palk, Bobby E. 2018 New Prairie Press The Impact of Colors on Learning. Roeper Review 7(4), p. 0-6.

Hope, Gill. (2012). Thinking and Learning Through Drawing in Primary Classrooms. California, US: SAGE PUblication.

Keiler, L.S. 2018. Teachers' roles and identities in student-centered classrooms. International Journal of STEM Education 5, 34.

Lali, Floriana, F, Basa, Sutarto, Joko, \& Setiawan, Deni. 2020. Finger Painting Learning to Stimulate Motor Development in Early Childhood Article Info. Journal of Primary Education 9(2), p.93-200.

Peraturan Menteri Pendidikan Nasional Nomor 16 Tahun 2007. Standar Kualifikasi Akademik dan Kompetensi Guru. 2007.

Prayitno. 2019. Pembelajaran Menggambar Berbasis Cerita di Taman-kanak. Jurnal Pendidikan Anak 8(2): p.149157.

Putri, Sevilia Sujarwo Indrias \& Trisakti. 2019. Pembelajaran Menggambar dengan 


\section{$\Delta \sqrt{\mathrm{j}} \mathrm{B}$ D] Vol.6 No.2 Januari 2021, hal. 140-146}

Accelerated Drawing Technique (ADT) untuk Anak Usia Dini. Jurnal Pendidikan Anak 8(2): p.107-115.

Tay-Lim, J, Lim, S. 2013. Privileging younger children's voices in research: Use of drawings and a co-construction process. International Journal of Qualitative Methods 12(1), p.65-83.

Zuliatin, Farid, Muhammad \& Denog, Wigati. 2013. Pengaruh Seni Finger Painitng Terhadap Pengetahuan Warna. Jurnal Penelitian Psikologi 4(2), p.181-192. 